\title{
More red tape than ever for Russians travelling abroad
}

Moscow. Crossing the borders of Russia has become almost as great a problem for Russian scientists as their financial troubles. The result is that most people agree that the bureaucratic obstacles to travelling abroad now compare with those familiar during the Communist regime.

Thus Ia Vaiskova, the director of the Travel-Grant Program of the International Science Foundation (established by the philanthropist George Soros), says that in the few months of the programme's operation, a hundred scientists were able to attend conferences abroad, but that roughly the same number of trips had to be cancelled because travel documents could not be processed in time.

The difficulties have been mounting since the turn of the year, when the Russian government set out to exchange existing USSR foreign passports (necessary for travel abroad) for Russian documents. The need for this exchange is still not clear: the new passport is the same as the USSR passport, but with a different serial number.

Officials claim that the exchange is needed to give up the old exit-visa system: all new passports are cleared by the successors of the $\mathrm{KGB}$, and do not require a stamp on leaving Russia. But the whole business has turned into a bureaucratic nightmare and an opportunity for bribery on a scale unprecedented even in Russia.

As a result, Russian scientists cannot attend many conferences and other events abroad. The International Science Foundation now makes it a rule that travel-grant recipients must have a foreign passport ten days before the departure date, to allow the paperwork to be processed. Otherwise, a scientist may lose a travel grant.

The situation is especially devastating in Moscow. Astrophysicist Alexei Fridman had to abandon plans to attend a conference to which he had been invited as a speaker because the passport exchange procedure requires at least two months. But his colleagues at St Petersburg were able to go, because travellers there can use the old passports provided they are from the most recent issue, known as Series 21.

Some Muscovites accordingly seek to leave Russia from other states of the former Soviet Union, such as Belarus. Others get out by bribery. An exit-visa stamp in the old, series-21, passport costs US $\$ 80-\$ 160$, the "rush fee" for a new passport ranges from $\$ 500$ upwards. Even worse, these services are by no means reliable. Every day, 60 to 80 people with forged stamps and passports are turned back from Moscow International Airport.

The difficulty in obtaining passports is not the only one. Fearful of being flooded by Russians now that exit-visas have been abandoned, the consulates of many countries have tightened their visa requirements. It is almost impossible to visit some countries at short notice. While the US consulate is relatively cooperative and there are few problems with travel to Israel, many European and Asian countries have erected barriers that are almost impossible to overcome.

Vaiskova says that restrictions are especially onerous with China and Japan. Their consulates refuse to start processing documents until they receive approval from their ministries of foreign affairs, which usually takes a month. Among European governments, the International Science Foundation encounters most problems with the French and Italian consulates.

It is difficult to find a word other than "harassment" for the treatment of Russian citizens at the French consulate. Sometimes, according to Vaiskova, scientists are invited

to pick up their visas an hour after the departure time indicated on their airline tickets. But many Russian scientists also complain about the humiliation they must suffer at the hands of the German staff.

Earlier this year, the Swiss consulate was highly regarded, but now it implements a quota system, awarding only 20 visas a day to the citizens of a country of 150 million people. As a result, a person needs to queue for several weeks to be allowed to deliver papers to the consulate.

Most consulates say they do not distinguish between the purposes for which Russians wish to travel, and that they treat immigrants, businessmen, students, scientists and tourists equally. Equality would be welcome if everybody was treated equally well. But if everybody is equally harassed, that is an egalitarianism all too familiar to Russians.

Michael Monastyrsky from the Institute of Theoretical and Experimental Physics, who is now waiting for a visa without being sure that he will receive it, even believes that the inconvenient and even brutal rules of the Communist past were better than the present bureaucratic abuse. "At least then you knew what could be done and what could be expected", he says.

Vladimir Pokrovsky

\section{Bomb attacks on US researchers}

San Francisco. US federal agents and university officials have warned researchers to be alert for suspicious packages after two prominent scientists were seriously injured by separate mail-bomb explosions in the same week.

On 22 June, a $81 / 2$ inch by 11 inch padded manila envelope exploded in the hands of 59-year-old Charles Epstein, a geneticist at the University of California, San Francisco, as he opened the package at his home. Two days later, a similar bomb critically injured David Gelernter (38), an associate professor at Yale, as he was opening mail in his office at the campus computer sciences building. Epstein lost three fingers and suffered a broken arm and abdominal injuries. Gelernter was badly injured in his chest and abdomen and may have a permanently damaged eye and hand.

The Federal Bureau of Investigation(FBI) links the two bombings to each other and to a dozen unsolved attacks between 1978 and 1987. Special agent Tim Bezick in San Francisco says the bombs' materials, construction, packaging and targets all point to the same individual or group. An earlier federal investigation was disbanded for lack of leads.

The FBI says it has found no link between the two researchers recently attacked, nor any motive for the bombings. The earlier explosions had targeted seven uni- versities, a computer store, Boeing Corporation and United Airlines. Bezick says the FBI has no idea why two attacks should suddenly have followed six years of quiet except the conjecture that the person responsible had been in prison or some other institution.

Bezick said it was not clear why the bomber had targeted a geneticist (Epstein) for the first time. A telephone threat the afternoon following Gelernter's injury seemed aimed at his brother Joel, who is a geneticist at Yale, but investigators believe that call may have been from a crank.

The FBI has sent an e-mail warning to university administrations urging them to warn staff about strange packages in the mail. Officials at Massachusetts Institute of Technology, Harvard University, the University of California at Berkeley, Yale University and the University of California at San Francisco all said they are taking special security precautions, but they also said they hope to avoid panic

Federal agents warn scientists to watch for rigid packages with markings such as "personal" or "confidential" a hand-written or poorly typed address, excessive postage, a lopsided shape or excessive securing material (such as string or tape). They warned researchers not to touch or cover such a package, and to move people away from it rather than to move the package itself.

Sally Lehman 